\title{
Avaliação das mutações causadoras de nanismo do tipo condrodisplásico em equinos da raça Mini-Horse
}

Danilo Giorgi Abranches de Andrade, Alexandre Secorun Borges, Jose Paes de Oliveira-Filho

Faculdade de Medicina Veterinária e Zootecnia, Universidade Estadual Paulista (UNESP), Botucatu, SP, Brasil

*Autor correspondente

e-mail: zefilho@fmvz.unesp.br

\section{Resumo}

O nanismo é uma forma de desenvolvimento anormal, determinado por genes que contribuem para uma pequena estatura e que podem interferir negativamente na saúde e reprodução da espécie afetada. Em equinos, o nanismo é descrito principalmente na raça Mini-Horse. Nessa raça, a enfermidade possui caráter autossômico recessivo e já foram descritas quatro mutações (D1, D2, D3 e D4), segregadas independentemente no gene Aggrecan (ACAN), responsáveis pelo nanismo condrodisplásico. Genotipos envolvendo mutação D1 provocam morte fetal, equanto que os outros genótipos estão envolvidos com nascimentos de animais clinicamente afetados. 0 objetivo desse trabalho foi avaliar as mutações causadoras do nanismo condrodisplásico (D1, D2, D3 e D4) em equinos da raça Mini-Horse, clinicamente afetados, provenientes de propriedades rurais do interior do estado de São Paulo. Entre os meses de outubro de 2015 e fevereiro de 2017, cinco equinos fenotipicamente anões foram avaliados. Destes, quatro eram neonatos e vieram a óbito com no máximo 48 horas de vida. Já o outro, tinha um ano de idade. Os sinais clínicos apresentados pelos equinos neonatos foram: cabeça grande e abaulada; prognatismo e membros curtos que evidenciavam más-formações ósseas, mais notoriamente nos metatarsos. Já o Mini-Horse de um ano, além da baixa estatura (53 cm de altura na cernelha), apresentou cabeça grande, corpo em forma de barril, membros curtos e sinais respiratórios como secreção nasal mucopurulenta e roncos. Amostras de sangue foram coletadas para genotipagem utilizando-se sequenciamento direto de produtos de PCR, que amplificavam os pontos das mutações responsáveis pelo nanismo já descritas. Uma vez que foram genotipados animais vivos, o genotipo D1 não foi observado; além disso, a genotipagem destes animais afetados não evidenciou os demais genótipos (D2/D2, D2/D3, D2/D4, D3/D3, D3/D4 e D4/D4) descritos anteriormente como responsáveis pela enfermidade. Consequentemente, a avaliação de mutações no gene ACAN, possivelmente causadoras de nanismo e ainda não relatadas, torna-se necessária para um melhor 
entendimento da enfermidade. Portanto, acredita-se que possivelmente exista outra mutação ocasionando o nanismo nos animais do interior paulista. Ressalta-se que o padrão de herança autossômico recessivo contribui para ampliar a disseminação da enfermidade no plantel de forma silenciosa, já que os progenitores (heterozigotos) são normais na aparência. Portanto, a identificação dos animais heterozigotos é importante para minimizar perdas econômicas e nascimentos de animais afetados, pois possibilita a seleção do acasalamento. Entretanto, estudos moleculares necessitam ser realizados com os animais brasileiros da raça Mini-Horse com o intuito de caracterizar possíveis novas mutações causadoras do nanismo.

Palavras-chave: Análise de sequência de DNA. Gene ACAN. Mutação.

Agradecimentos: à Fundação de Amparo à Pesquisa do Estado de São Paulo pelo financiamento da pesquisa (FAPESP 2016/24767-7). 